\title{
Eighty Years of Succession in a Noncommercial Plantation on Hawai'i Island: Are Native Species Returning? ${ }^{1}$
}

\author{
Foseph Mascaro $^{2}$
}

\begin{abstract}
Hawai'i's forest ecosystems are changing rapidly due to a high level of species introductions, and it is an open question whether native species will be maintained. Several studies have explored the potential for native species to succeed in future communities dominated by introduced species in Hawai' $i$, but the results have been conflicting and most of the studies have been limited to relatively young forest ( $<30 \mathrm{yr}$ old). I surveyed a remote, 80 -yr-old noncommercial plantation on Hawai'i Island to determine whether any native tree species were able to succeed in the planted forest. I compared abundance and composition of native species in the plantation to that in a relict, native-dominated forest adjacent to the plantation and located on the same substrate type. After $80 \mathrm{yr}$, native species constituted just $4.5 \%$ of basal area and $12.1 \%$ of stem density in the plantation. However, I found that the relative success of native species varied strongly by species. Of nine native species encountered in the relict forest, six were rare or absent in the planted forest. A seventh (Metrosideros polymorpha) dominated the relict forest but was unable to recruit in the planted forest. However, two shade-tolerant understory tree species (Psychotria hawaiiensis and Psydrax odorata) were at least as common in the plantation as in the relict forest, and the latter was significantly more abundant in the plantation. Thus, although I found no evidence that native species will dominate with continued succession, I found that at least two native species may remain important components of plantation-derived Hawaiian forests in the future.
\end{abstract}

A LONG History of land-use change and species introductions has dramatically transformed most Pacific island ecosystems. The high level of endemism in Pacific floras and narrow range of life-history strategies in many groups have made island ecosystems

${ }^{1}$ This project was supported by an NSF Doctoral Dissertation Improvement Grant to S. Schnitzer, R. F. Hughes, and J.M., as well as a Graduate Research Fellowship award to J.M. Manuscript accepted 14 February 2010.

${ }^{2}$ Department of Biological Sciences, University of Wisconsin-Milwaukee, Lapham Hall, 3209 North Maryland Avenue, Milwaukee, Wisconsin 53211. Present address: Department of Global Ecology, Carnegie Institution for Science, 260 Panama St., Stanford, CA 94035.

Pacific Science (2011), vol. 65, no. 1:1-15

doi: 10.2984/65.1.001

(C) 2011 by University of Hawai'i Press

All rights reserved particularly sensitive to colonization by introduced species (Mueller-Dombois 2008). In Hawai' $i$, the most isolated archipelago in the Pacific, introduced species often colonize remote ecosystems with minimal disturbance or human modification (Asner et al. 2008). As early as the 1940s, some predicted the complete loss of native tropical forests in Hawai'i (Egler 1942).

Today, the highest conservation priority in Hawai' $i$ is to preserve what remains of mostly intact native ecosystems. But there is increasing interest in ecosystems dominated by introduced species. The growing interest is motivated by several factors. First, exoticdominated ecosystems in Hawai' $i$ provide many ecosystem services in areas where historical native ecosystems are now entirely absent. These services include carbon storage and sequestration, erosion control and watershed protection, and the provision of basic natural goods such as timber (Woodcock 
2003, Ewel and Putz 2004). Second, although exotic-dominated ecosystems are radically transformed, the uniqueness of Hawai'i's biodiversity and high risk of endemic species extinction has led to some consideration of the restoration of exotic-dominated ecosystems to historically accurate native-dominated states. In one study, Ostertag et al. (2009) found that clearing introduced species in a nearly exotic-dominated lowland forest ( $\sim 45 \%$ of basal area) resulted in a substantial recovery of native species that were otherwise unable to regenerate. However, the removal plots were small (10 by $10 \mathrm{~m})$, and the effort was deemed cost-prohibitive at a large scale.

A third consideration, which is the focus of this study, is that many exotic-dominated ecosystems in other regions accumulate native species over the course of succession without active management. For example, exotic-dominated forests on Puerto Rico initially have no native species when they emerge after agricultural abandonment but contain native and introduced species in roughly equal abundance after 40 yr (Lugo 2004). Similarly, exotic-dominated forests in Seychelles support a variety of endemic plant species where no native habitat remains (Kueffer et al. 2007). There have been several studies attempting to determine whether exotic-dominated forests on Hawai'i contain an important component of native plant diversity, although these studies have produced contradictory results. Two studies found a limited amount of native regeneration under plantations of introduced species (Harrington and Ewel 1997, Woodcock et al. 1999), and three studies, including one that sampled the same region as Harrington and Ewel (1997), found natives in low abundance in both planted and nonplanted exotic-dominated forests (Constantinides and Cannarella 1999, Mascaro et al. 2008, Ostertag et al. 2008). In addition, young forests have been preferentially sampled. Of the five studies just cited, only two (Woodcock et al. 1999, Mascaro et al. 2008) sampled forest sites $>30 \mathrm{yr}$ old. Thus, it remains an open question whether continued succession in exotic-dominated Hawaiian forests will be accompanied by a return of native plant species.
To address this question, I surveyed an 80year-old noncommercial plantation in the remote Muliwai region of the Kohala Forest Reserve on Hawai'i Island. In addition to the plantation, the Muliwai region contains relict forest dominated by the native Metrosideros polymorpha ('ōbi'a), which provides a general (not pristine) baseline of native species richness and abundance.

\section{MATERIALS AND METHODS}

\section{Study Area and Management History}

The study area was the Muliwai section of the Kohala Forest Reserve on the island of Hawai' $i$, specifically within a $1 \mathrm{~km}$ by $3 \mathrm{~km}$ strip of forest along the Muliwai Trail between Waipi ${ }^{\prime} \mathrm{o}$ and Waimanu valleys $\left(20^{\circ} 07^{\prime}\right.$ $\left.\mathrm{N}, 155^{\circ} 36^{\prime} \mathrm{W}\right)$. The planting occupies approximately $75 \%$ of the study area; the remainder is occupied by several fragments of relict native forest dominated by $M$. polymor$p h a$. The area ranges from 350 to $500 \mathrm{~m}$ in elevation, receives between 1,500 and 2,000 $\mathrm{mm}$ of rainfall per year, and is classified as tropical moist forest (Giambelluca et al. 1986). Soils are poorly drained clayey inceptisols of the Amalu Series, derived from 250,000 - to 750,000 -yr-old basaltic lava and ash (Wolfe and Morris 1996, U.S. Department of Agriculture 2009).

Most of the study area was planted with introduced trees in the 1930s. Historical records were kept irregularly during the Depression (Woodcock 2003) and only anecdotal references to the study area could be located. Records and photographs are abundant, however, for nearby Waipi'o and Waimanu valleys, and these areas were heavily degraded in 1930. It is probable that the study area was similarly degraded from a combination of fire and erosion and that these disturbances were the impetus for planting ( $\mathrm{S}$. Bergfeld, Hawai'i Division of Forestry and Wildlife, pers. comm.). An alternative possibility is that native forest, often deemed ineffective for management (Woodcock 2003), was actively cleared to make way for planting. Although agricultural activity was (and still is) prevalent in Waipi'o and Waimanu valleys, it 
is unlikely that the planted area in Muliwai was used in this way. The land is highly exposed with shallow soils, and there are no residual crop species, which are a common feature of reverted lands elsewhere on the Hawaiian Islands (Mascaro et al. 2008). The remote, roadless location and the high diversity of species planted without visible rows suggests that the plantation was noncommercial (i.e., not intended for future harvest). Although it is regularly accessed by hunters, there is no evidence of major human disturbance since the planting. The Hawai'i Division of Forestry and Wildlife conducts sporadic control of introduced species, primarily Clidemia birta (Koster's curse), very close to the trail, but to date there are no efforts to perform out-planting or otherwise improve the standing of native species.

\section{Sampling Methods}

In May and June of 2009, 46 permanent 500 $\mathrm{m}^{2}$ circular plots (12.62 $\mathrm{m}$ radius) were established within the study area, 26 in planted forest and 20 in relict native forest. The plots were placed in a stratified design (50 m center to center) along a series of transects placed perpendicular to the Muliwai Trail, ranging from 50 to $300 \mathrm{~m}$ from the trail. The arrangement of plots was limited by the steep grade of much of the study area, as well as the distribution of the planted and relict forests. Each plot was marked with a PVC stake at the center and a GPS point (with a receiver [Garmin 76cx] for a minimum of 600 measurements). Within each plot, I sampled all trees, palms, tree ferns, and lianas that reached $1.3 \mathrm{~m}$ in height (i.e., no minimum size class), recording the identity to species and diameter at breast height $(\mathrm{dbh}, 1.3 \mathrm{~m}$ from the ground) or above buttress. I treated attached ramets as separate stems provided that they diverged from the main stem below $1.3 \mathrm{~m}$ in height and were vertically oriented; I excluded branches. My sampling methods differed for two groups with unique growth forms: (1) tree ferns for which the fronds but not the caudice reached $1.3 \mathrm{~m}$ in height were recorded for stem density but not basal area, and (2) stems of C. birta, an introduced species that branches heavily at breast height, were counted at the base and excluded from basal area measurements. For individuals $<4$ $\mathrm{cm}$ dbh, I used dial calipers to measure diameter to the nearest millimeter; I used metal dbh tapes for all other individuals. Given the difficulty in accessing the study area, and because Hawai'i has numerous introduced tree species that reach extreme stem densities in localized areas, a density-dependent sampling method was employed in a limited number of situations. If a species reached a density of $5,000 \mathrm{stems} / \mathrm{ha}$ in the first quadrant of each circular plot (i.e., $\geq 62$ measured stems within $12.62 \mathrm{~m}$ radius and a bearing of $0^{\circ}$ to $90^{\circ}$ ), only individuals $\geq 10 \mathrm{~cm}$ dbh were measured thereafter. All species abundance data were then weighted based on the area sampled. This method was chosen to preserve the integrity of species richness and basal area measurements, while still providing a useful picture of the full range of size classes for all species. No native species reached this threshold of abundance. Within each plot, I also recorded the identity and abundance of seedlings $<1.3 \mathrm{~m}$ in height in a $1 \mathrm{~m}$ by $5 \mathrm{~m}$ subplot between 5 and $10 \mathrm{~m}$ north of the plot center and extending $1 \mathrm{~m}$ east of a bearing of $0^{\circ}$. The placement was intended to avoid trampling at the plot center.

\section{Data Analysis}

Due to a high number of zero values, species abundances were not normally distributed. I compared species abundances between planted and relict forest types using nonparametric Mann-Whitney $U$ tests (www .r-project.org).

I created histograms of species abundances by binning stems into $202.5 \mathrm{~cm}$ dbh size classes from 0 to $50 \mathrm{~cm}$ dbh for each species in a given forest type. I graphed the results by centering each data column around the median dbh of each size class (e.g., the first size class ranged from 0 to $2.49 \mathrm{~cm} \mathrm{dbh}$, inclusive, and was centered at $1.25 \mathrm{~cm} \mathrm{dbh}$ when graphed). Each graph also included a composite bin category for all stems $>50 \mathrm{~cm}$ $\mathrm{dbh}$, which was centered at $51.25 \mathrm{~cm}$ when graphed. 
TABLE 1

Relative Basal Area of the 10 Most Dominant Species and All Native Species Found in an 80-yr-old Noncommercial Plantation in Muliwai and an Adjacent Relict Native-Dominated Forest (Hawaíi Island)

\begin{tabular}{|c|c|c|c|c|c|}
\hline \multicolumn{3}{|c|}{ Planted Forest } & \multicolumn{3}{|c|}{ Relict Forest } \\
\hline Species & $\begin{array}{c}\text { Relative Basal } \\
\text { Area (\%) }\end{array}$ & Rank & Species & $\begin{array}{c}\text { Relative Basal } \\
\text { Area (\%) }\end{array}$ & Rank \\
\hline Ten most dominant & & & Ten most dominant & & \\
\hline Falcataria moluccana & 22.4 & 1 & Metrosideros polymorpha & 49.7 & 1 \\
\hline Melaleuca quinquenervia & 18.0 & 2 & Psidium guajava & 17.7 & 2 \\
\hline Casuarina glauca & 10.4 & 3 & Cordyline fruticosa & 12.0 & 3 \\
\hline Grevillea robusta & 7.0 & 4 & Melaleuca quinquenervia & 4.0 & 4 \\
\hline Eucalyptus robusta & 6.9 & 5 & Toona ciliata & 2.9 & 5 \\
\hline Fraxinus ubdei & 5.8 & 6 & Aleurites moluccana & 2.3 & 6 \\
\hline Araucaria columnaris & 5.1 & 7 & Antidesma platyphyllum & 1.8 & 7 \\
\hline Mangifera indica & 3.4 & 8 & Psychotria bawaiiensis & 1.4 & 8 \\
\hline Syzygium jambos & 3.3 & 9 & Cibotium menziesii & 1.3 & 9 \\
\hline Psidium guajava & 2.9 & 10 & Falcataria moluccana & 1.2 & 10 \\
\hline All native species & & & Other native species & & \\
\hline Psychotria bawaiiensis & 1.9 & 13 & Cibotium glaucum & 0.6 & 14 \\
\hline Metrosideros polymorpha & 1.8 & 14 & Psydrax odorata & 0.3 & 18 \\
\hline Psydrax odorata & 0.7 & 18 & Myrsine lessertiana & 0.1 & 22 \\
\hline Myrsine lessertiana & $<0.1$ & 28 & Diospyros sandwicensis & $<0.1$ & 29 \\
\hline Diospyros sandwicensis & $<0.1$ & 31 & Wikstroemia sp. & $<0.1$ & 31 \\
\hline Total & & & Total & & \\
\hline Native & 4.5 & & Native & 55.2 & \\
\hline Introduced & 95.5 & & Introduced & 44.8 & \\
\hline
\end{tabular}

Note: Boldface indicates native species. For a listing of all species, see Appendix.

RESULTS

After $80 \mathrm{yr}$ of succession in a noncommercial plantation, native species constituted just $4.5 \%$ of basal area and $12.1 \%$ of stem density (Tables 1 and 2). Of nine native tree species found in all plots, two species were rare in both forest types: Diospyros sandwicensis (lama) was found in only one plot in each forest, and Wikstroemia spp. ('akia) were found in only one relict forest plot. Five native species that were common in relict native forest were either absent or rare in planted forest (Antidesma platyphyllum [bame], Cibotium glaucum [bapu'u], Cibotium menziesii [bapu'u], M. polymorpha, and Myrsine lessertiana [kōlea]) (Figure 1). However, two native tree species (Psychotria hawaiiensis [kōpiko] and Psydrax odorata [alabe'e]) were common in the planted forest (Table 2). The abundance of P. hawaiiensis did not differ significantly between the relict and planted forests $(U=248$,
$\left.P=.7982, n_{1}=26, n_{2}=20\right)$, and $P$. odorata was significantly more abundant in the planted forest $\left(U=146.5, P=.0074, n_{1}=\right.$ $26, n_{2}=20$ ) (Figure 1). These low-stature tree species each exceeded $15 \mathrm{~cm} \mathrm{dbh}$ and had strong recruitment curves in both relict and planted forest, suggesting that they are completing their life cycle (Figure 2). By contrast, the recruitment curves of the native dominant $M$. polymorpha suggest that only scattered individuals have succeeded in the planted forest and indicate relatively poor recruitment of young individuals in the relict forest.

Both P. odorata and P. hawaiiensis were also found at the seedling stage in the planted forest, although at relatively low abundances compared with the introduced species (Table $3)$. These were the only native species found at the seedling stage in the planted forest.

In addition to the lack of native species in the planted forest, the relict forest was domi- 
TABLE 2

Relative Density of the 10 Most Abundant Species and All Native Species Found in an 80-yr-old Noncommercial Plantation in Muliwai and an Adjacent Relict Native-Dominated Forest (Hawai'i Island)

\begin{tabular}{|c|c|c|c|c|c|}
\hline \multicolumn{3}{|c|}{ Planted Forest } & \multicolumn{3}{|c|}{ Relict Forest } \\
\hline Species & $\begin{array}{c}\text { Relative } \\
\text { Density (\%) }\end{array}$ & Rank & Species & $\begin{array}{c}\text { Relative } \\
\text { Density (\%) }\end{array}$ & Rank \\
\hline Ten most abundant & & & Ten most abundant & & \\
\hline Araucaria columnaris & 20.0 & 1 & Clidemia birta & 42.7 & 1 \\
\hline Cordyline fruticosa & 17.3 & 2 & Cordyline fruticosa & 25.7 & 2 \\
\hline Syzygium jambos & 14.5 & 3 & Psidium guajava & 13.2 & 3 \\
\hline Psychotria hawaiiensis & 8.8 & 4 & Psychotria bawaiiensis & 3.7 & 4 \\
\hline Casuarina glauca & 6.9 & 5 & Metrosideros polymorpha & 3.7 & 5 \\
\hline Clidemia birta & 6.7 & 6 & Psidium cattleianum & 2.0 & 6 \\
\hline Psidium guajava & 5.4 & 7 & Psydrax odorata & 1.5 & 7 \\
\hline Fraxinus ubdei & 3.5 & 8 & Antidesma platyphyllum & 1.2 & 8 \\
\hline Psydrax odorata & 2.9 & 9 & Toona ciliata & 1.0 & 9 \\
\hline Coffea arabica & 2.5 & 10 & Falcataria moluccana & 0.8 & 10 \\
\hline Other native species & & & Other native species & & \\
\hline Metrosideros polymorpha & 0.3 & 21 & Cibotium glaucum & 0.5 & 13 \\
\hline Myrsine lessertiana & $<0.1$ & 28 & Cibotium menziesii & 0.2 & 17 \\
\hline Diospyros sandwicensis & $<0.1$ & 32 & Myrsine lessertiana & 0.2 & 18 \\
\hline \multirow[t]{2}{*}{ Cibotium glaucum } & $<0.1$ & 34 & Wikstroemia sp. & $<0.1$ & 29 \\
\hline & & & Diospyros sandwicensis & $<0.1$ & 32 \\
\hline Total & & & Total & & \\
\hline Native & 12.1 & & Native & 11.0 & \\
\hline Introduced & 87.9 & & Introduced & 89.0 & \\
\hline
\end{tabular}

Note: Boldface indicates native species. For a listing of all species, see Appendix.

nated by roughly equal parts native $(55 \%$ of basal area) and introduced species (45\%) (Table 1$)$. The native component was nearly all M. polymorpha (50\% of basal area), and the introduced component consisted primarily of the short-stature introduced trees Psidium guajava (common guava) and Cordyline fruticosa $(t i)$. Notably, both of these introduced species were less abundant in the planted forest both as stems $\geq 1.3 \mathrm{~m}$ in height (Table 2) and as seedlings (Table 3 ). Similarly, the introduced $C$. birta attained the highest relative abundance in the relict forest and was less abundant in the plantation (Table 2).

The plantation was dominated by very large tree species widely planted in the 1930 s throughout Hawai'i (Woodcock 2003) (Table 1). Areas of level grade, to which most of my sampling was constrained, were planted primarily with a mix of Falcataria moluccana (albizia), Melaleuca quinquenervia (paperbark), Eucalyptus robusta (swamp mahogany), Fraxi- nus ubdei (tropical ash), and Araucaria columnaris (Cook pine). Ridges and slopes were primarily planted with Casuarina glauca (ironwood) and Grevillea robusta (silk oak), and steep valleys and watercourses were primarily planted with Terminalia myriocarpa (jhalna). The plantation also included a minor component of large ornamental tree species (e.g., Ficus elastica [rubber fig], Taxodium distichum [bald cypress]), and patches of fruit trees (e.g., Macadamia integrifolia [macadamia nut], Citrus limon [lime], and Coffea arabica [coffee]) (Appendix). Recruitment curves suggest that some planted species are recruiting strongly (e.g., A. columnaris and C. glauca), but others are unable to recruit (e.g., E. robusta and $G$. robusta) (Figure 3).

\section{DISCUSSION}

Lowland Hawaiian forests have entered a period of rapid change, and it is an open 


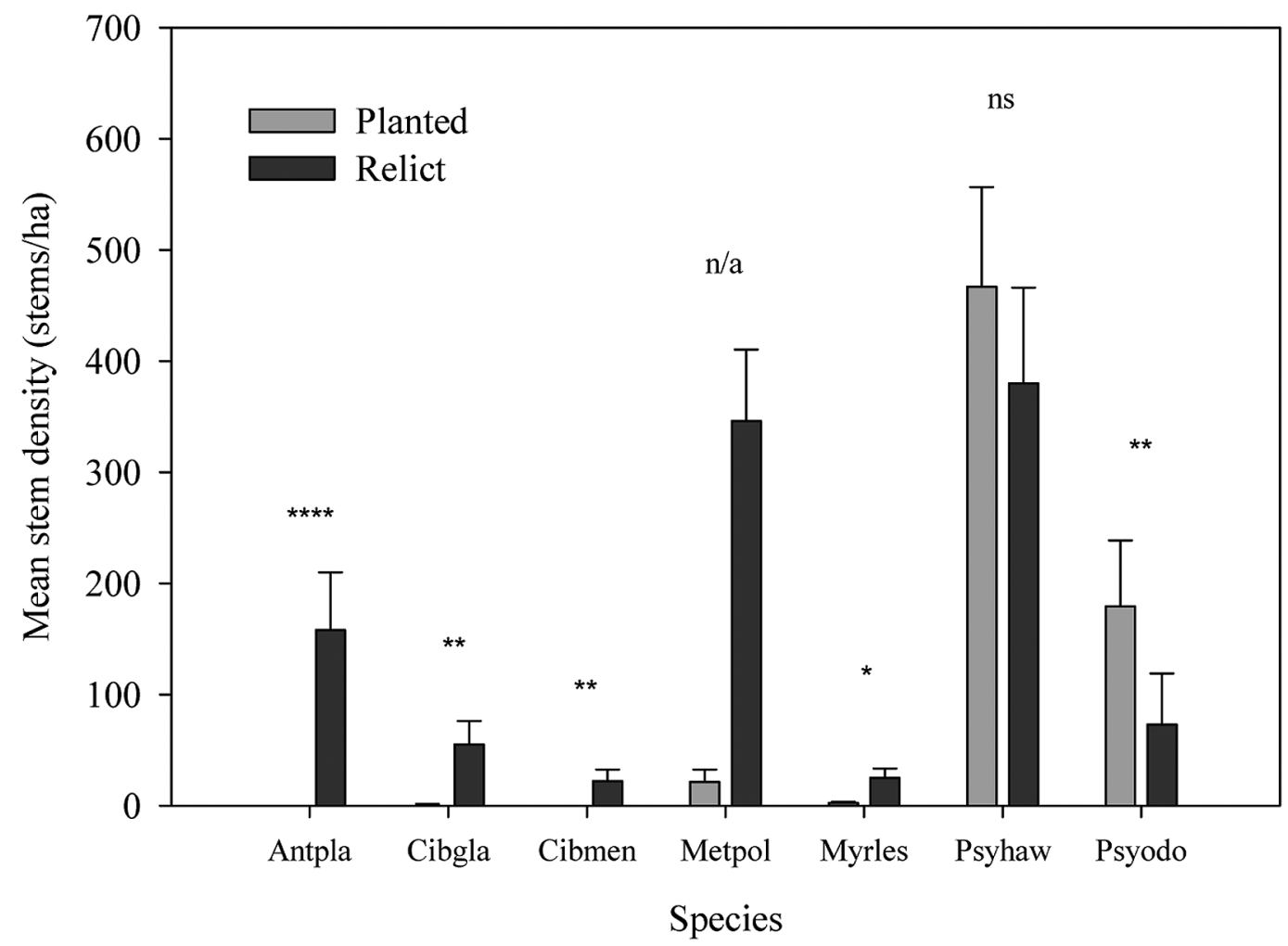

FigUre 1. Abundance of seven native species in planted ( $n=26$ plots) versus relict $(n=20$ plots) native forest in the Muliwai region of Hawai'i Island (Antpla, Antidesma platyphyllum; Cibgla, Cibotium glaucum; Cibmen, Cibotium menziesii; Metpol, Metrosideros polymorpha; Myrles, Myrsine lessertiana; Psyhaw, Psychotria hawaiiensis; Psyodo, Psydrax odorata). Significance levels reflect the results of Mann-Whitney $U$ tests. No test was performed on $M$. polymorpha, which dominated all the relict forest plots by design. ns, nonsignificant; ${ }^{*}, P<.05$; ${ }^{* *}, P<.01$; ${ }^{* * *}, P<.0001$.

question whether native tree species will be maintained. After $80 \mathrm{yr}$ of succession, I found that the dominant native canopy tree $(M$. polymorpha), as well as the dominant native midcanopy tree ferns (Cibotium spp.), have thus far been unable to succeed in the plantation. Mueller-Dombois (2008) made the case that the native Hawaiian tree flora lacks dominant canopy species with the clear successional roles we typically ascribe to tropical tree species, such as r-selected, fast-growing pioneer species, and K-selected, slowgrowing shade-tolerant species (Denslow 1980). For example, M. polymorpha tends toward high intolerance of shade and slow growth-traits that are likely causing its niche space to collapse in the presence of hundreds of new competitors. Observational studies have found that $M$. polymorpha dominance in lowland (and some midelevation) regions of Hawai' $i$ is eroding rapidly and lacking in regeneration (Hughes and Denslow 2005, Mascaro et al. 2008, Ostertag et al. 2008, Zimmerman et al. 2008), and experimental studies have found that $M$. polymorpha cannot compete for resources against introduced tree species in lowland wet conditions (Funk and Vitousek 2007, Ostertag et al. 2009). In support of these conclusions, I found that $M$. polymorpha was largely unable to recruit into a planted forest after $80 \mathrm{yr}$ of succession despite an ample seed source from 


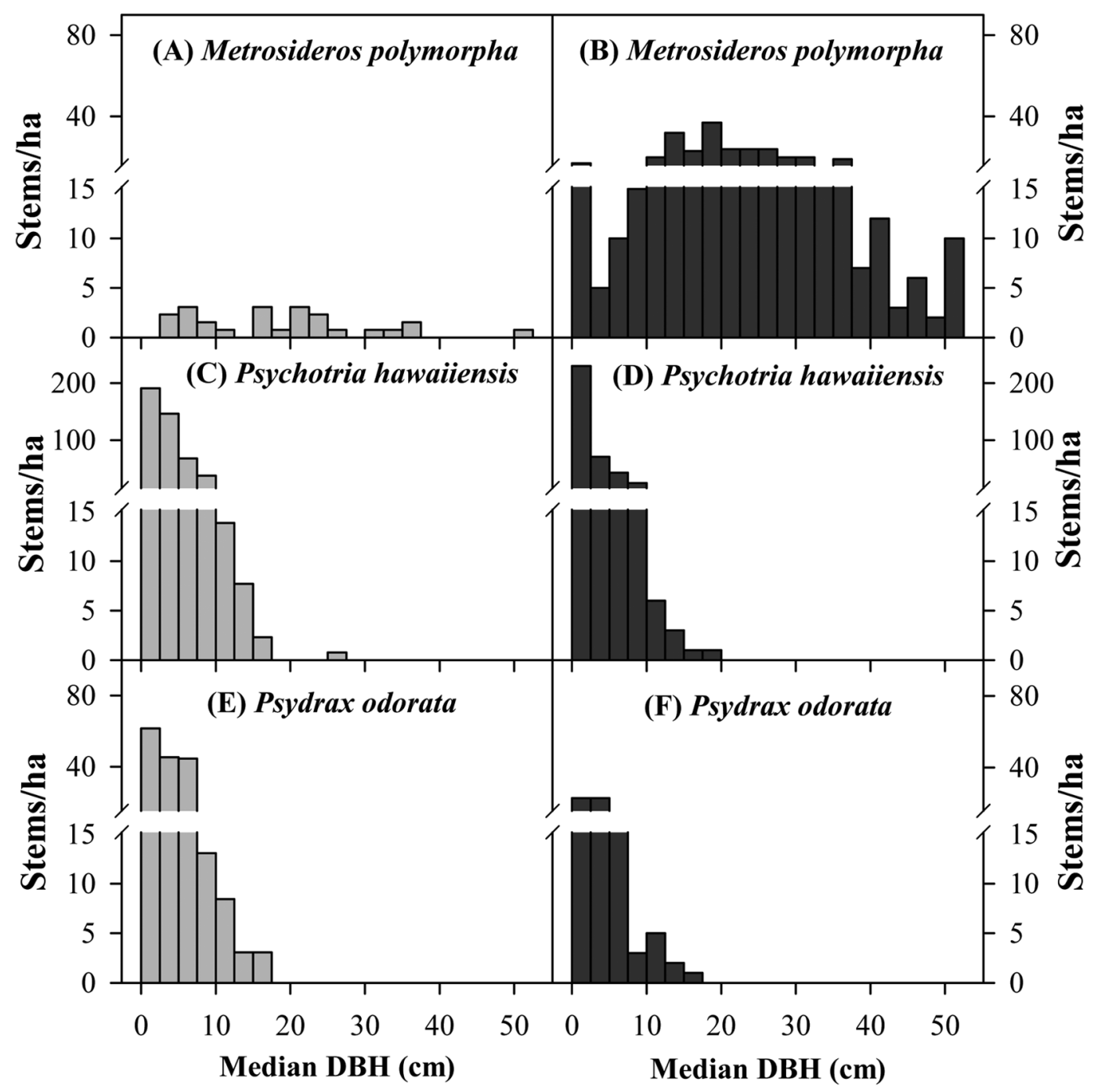

FiguRE 2. Recruitment curves for three native tree species in both an 80 -yr-old noncommercial plantation (light gray bars) and an adjacent relict, native-dominated forest (dark gray bars) in the Muliwai region of Hawai' $i$ Island. On the $x$-axis, the highest median dbh (diameter at breast height) category includes all stems $>50 \mathrm{~cm}$. Note the different scales on the $y$-axes among species.

a nearby relict native forest, as evidenced by a very low abundance of low-statured stems and lack of seedlings. Furthermore, I found that $M$. polymorpha had poor recruitment in the relict forest, suggesting that continued succession there will lead to a gradual loss of this dominant canopy tree. Metrosideros poly- morpha often depends on gaps to maintain dominance in closed-canopy forest (MuellerDombois 2008) and might reasonably be expected to colonize gaps in the plantation. However, because low-statured stems and seedlings of $M$. polymorpha were rare and absent, respectively, I suggest that there is no 
TABLE 3

Relative Density of the 10 Most Abundant Seedlings and All Native Seedlings Found in an 80-yr-old Noncommercial Plantation in Muliwai and an Adjacent Relict Native-Dominated Forest (Hawai'i Island)

\begin{tabular}{|c|c|c|c|c|c|}
\hline \multicolumn{3}{|c|}{ Planted Forest } & \multicolumn{3}{|c|}{ Relict Forest } \\
\hline Species & $\begin{array}{l}\text { Relative Seedling } \\
\text { Density (\%) }\end{array}$ & Rank & Species & $\begin{array}{c}\text { Relative Seedling } \\
\text { Density (\%) }\end{array}$ & Rank \\
\hline Ten most dominant & & & Ten most dominant & & \\
\hline Falcataria moluccana & 55.7 & 1 & Psidium guajava & 24.1 & 1 \\
\hline Coffea arabica & 18.2 & 2 & Psidium cattleianum & 23.1 & 2 \\
\hline Syzygium jambos & 12.3 & 3 & Falcataria moluccana & 22.2 & 3 \\
\hline Fraxinus ubdei & 4.6 & 4 & Clidemia birta & 16.7 & 4 \\
\hline Araucaria columnaris & 2.7 & 5 & Cordyline fruticosa & 5.6 & 5 \\
\hline Clidemia birta & 2.2 & 6 & Rubus rosifolius & 3.7 & 6 \\
\hline Psydrax odorata & 2.2 & 7 & Psychotria bawaiiensis & 1.9 & 7 \\
\hline Casuarina glauca & 0.5 & 8 & Syzygium jambos & 1.9 & 8 \\
\hline Cordyline fruticosa & 0.5 & 9 & Cibotium menziesii & 0.9 & 9 \\
\hline Psidium cattleianum & 0.5 & 10 & & & \\
\hline Other native species & & & & & \\
\hline Psychotria bawaiiensis & 0.1 & 13 & & & \\
\hline Total & & & Total & & \\
\hline Native & 2.3 & & Native & 2.8 & \\
\hline Introduced & 97.7 & & Introduced & 97.2 & \\
\hline
\end{tabular}

Note: Boldface indicates native species.

cohort of available $M$. polymorpha individuals available to take advantage of such opportunities.

Metrosideros polymorpha may be able to recruit in forests dominated by introduced species in limited situations with some combination of dry conditions, high light, low nutrient availability, or high elevation (i.e., with lower pressure from introduced species). Mueller-Dombois (2008) observed strong recruitment of $M$. polymorpha along with several introduced tree species near Kalapana (Hawai'i Island). Although the area is at low elevation, lavas are young and strongly nutrient limited, providing a high-stress and highlight environment that may favor M. polymorpha. Harrington and Ewel (1997) and Constantinides and Cannarella (1999) found that $M$. polymorpha recruited beneath $\sim 25$-yr-old plantings of Eucalyptus spp., Toona ciliata (red cedar), and $F$. ubdei in the Waiākea Timber Management Area on Hawai'i Island. However, recruitment occurred primarily above $350 \mathrm{~m}$ elevation in an area of planted forest surrounded entirely by undisturbed native forest. The Waiākea Timber Management Area is located on strongly nutrient-limited lava that was never in a nonforest land-use state (contrary to most plantings on Hawai' $i$ Island), suggesting that the Waiākea Timber Management Area may not be representative of $M$. polymorpha regeneration under introduced species even at higher elevation. In addition, current work near the Waiākea Timber Management Area suggests that $M$. polymorpha recruitment is rapidly declining as Psidium cattleianum (strawberry guava) advances into higher-elevation forests (J. Denslow, U.S. Forest Service, pers. comm.). On O'ahu, Woodcock et al. (1999) found that $M$. polymorpha was a common understory component of a Melaleuca forest planted in the 1930s (275 m elevation). Woodcock et al. speculated that the high light availability in the ridge-top conditions may have allowed $M$. polymorpha to recruit into the plantation. Even after $70 \mathrm{yr}$ of growth, however, no $M$. polymorpha trees were taller than $1.5 \mathrm{~m}$.

Two common tree fern species (Cibotium spp.) that characterize nearly all native rain 


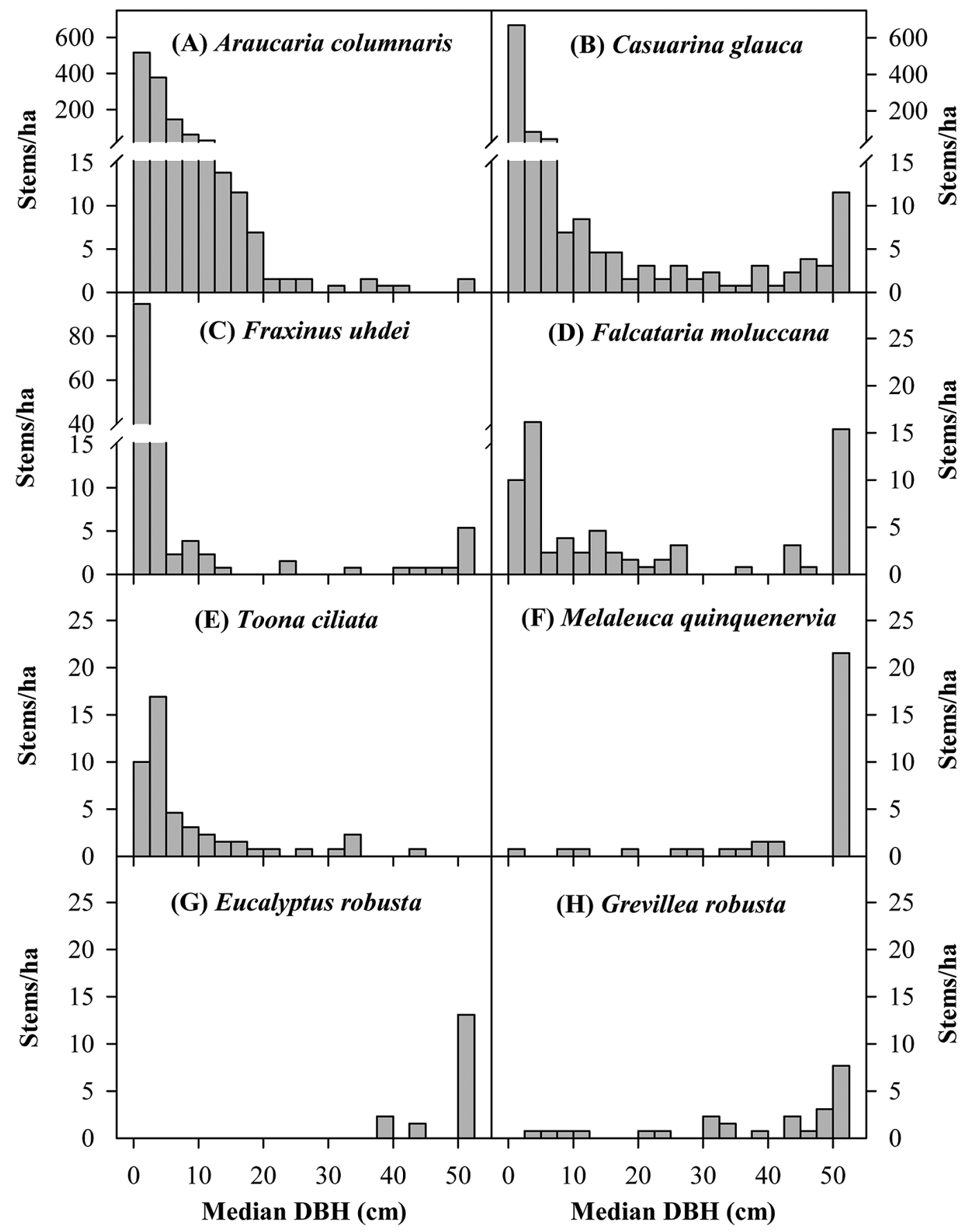

FIgURE 3. Recruitment curves for eight large introduced tree species planted in the Muliwai region of Hawai'i Island during the 1930s. Five species are naturalized and regenerating with varying success, and three species have failed to regenerate (although these three species are naturalized in other areas of Hawai' $i$ [Wagner et al. 1999]). On the $x$-axis, the highest median dbh (diameter at breast height) category includes all stems $>50 \mathrm{~cm}$. Note the different scales on the $y$-axes. 
forests on Hawai' $i$ were nearly absent in the planted forest. These species were also nearly absent in novel (nonplanted) lowland forests surveyed by Mascaro et al. (2008), but like $M$. polymorpha, they recruited strongly in high-elevation areas of the Waiakea Timber Management Area (Harrington and Ewel 1997, Constantinides and Cannarella 1999). As late-successional shade-tolerant species, the failure of Cibotium spp. to succeed in the planted forest suggests a different mechanism than the niche collapse observed for $M$. polymorpha. A probable cause is the high abundance of feral ungulates, which feed on the caudices of tree ferns. In areas where tree ferns are quite common, such as the relict forest studied here, ungulates typically do not cause enough damage to lead to declining Cibotium spp. abundance but may play a role in limiting their recruitment (Sweetapple and Nugent 2004).

With the absence of dominant species such as M. polymorpha and Cibotium spp., Hawaiian rain forests of the future will differ dramatically from their current composition. But will they lose all native tree species? I found evidence that two common native understory species, $P$. hawaiiensis and $P$. odorata, may continue to persist. Each of these species reached its maximum size beneath the plantation (according to Wagner et al. 1999) and appeared to be regenerating successfully based on recruitment curves of all individuals reaching $1.3 \mathrm{~m}$ in height (Figure 2) and detectable levels of seedlings (Table 3). Notably, I found more stems/ha for both species in the planted compared with the relict forest, and $P$. odorata was significantly more abundant in the planted forest. In a previous study, Mascaro et al. (2008) found that $P$. odorata was more abundant in novel (nonplanted) forests dominated by $F$. moluccana and Casuarina equisetifolia (ironwood) than it was in nearby relict native forests in lower Puna on Hawai'i Island. Those authors also found that $P$. hawaiiensis was the most abundant native understory component in a survey of 46 novel forests dominated by introduced species across Hawail $i$ Island. Combined with the results presented here, these data suggest that both $P$. odorata and P. hawaiiensis are established native components of introduced forests on Hawai'i.

The success of $P$. odorata and $P$. hawaiiensis compared with $M$. polymorpha is likely due in part to their high tolerance of shade. The shift from dominance by $M$. polymorpha to introduced trees, particularly the gymnosperm A. columnaris, which is reproducing prolifically in the plantation, typically results in a much darker understory and a light regime intolerable to $M$. polymorpha (Hughes and Denslow 2005, Ostertag et al. 2008). Although I did not measure light availability, total basal area in the planted forest $(71 \pm 8$ $\mathrm{m}^{2} / \mathrm{ha}$ ) was $65 \%$ higher than in the relict forest $\left(43 \pm 4 \mathrm{~m}^{2} / \mathrm{ha}\right.$ ) (data not shown), suggesting substantially higher leaf area and thus light interception.

Shade tolerance did not guarantee success, however. In contrast to the success in the plantation of $P$. odorata and $P$. hawaiiensis, two other functionally similar species ( $A$. platyphyllum and $M$. lessertiana) have failed to succeed in the plantation. Several nonmutually exclusive mechanisms could be responsible for the relative success of some native understory tree species over others in the planted forest, including herbivore pressure (Cabin et al. 2000, Sweetapple and Nugent 2004, Joe and Daehler 2008), the availability of pollinator and dispersal agents (Foster and Robinson 2007), and seed predation (Wagner et al. 1999). Each of these mechanisms has been documented to play a role in changing community compositions on $\mathrm{Ha}-$ wai'i. Throughout the Hawaiian Islands, for instance, herbivory by ungulates and slugs directly impedes the regeneration of certain native species, with the impacts distributed inequitably among species (Cabin et al. 2000, Sweetapple and Nugent 2004, Joe and Daehler 2008). On Maui, some native tree species are able to utilize introduced frugivorous birds for dispersal in a planted forest, favoring their recruitment over that of other native tree species (Foster and Robinson 2007). In this case the native frugivores that formerly dispersed the native tree species are extinct. Finally, seed predators such as introduced rats preferentially target certain native tree species but not others; they are an extreme 
threat to the endangered Pritchardia spp. (Wagner et al. 1999). Additional research is needed to determine the specific mechanisms behind the relative success of native understory tree species in new forests on Hawai' $i$.

Although this study targeted one of the oldest planted forests on Hawai'i, succession is continuing, and the prospects for native species could change. As the initial cohort of planted trees begins to die, gaps and landslide disturbances will create new regeneration opportunities that will likely cause the overstory composition to change. At a minimum, this will change the relative abundances of the introduced species that dominate the forest. For example, three of the five most dominant introduced species, $M$. quinquenervia, E. robusta, and $G$. robusta, have produced virtually no recruits in $80 \mathrm{yr}$ (Table 1, Figure $3 F-H$ ), while the remaining two, $A$. columnaris and $C$. glauca, are regenerating strongly (Table 1 , Figure $3 A-B)$. In addition, several introduced pioneer species that were not part of the initial plantation and currently occur in low abundance in the plantation, such as Cecropia obtusifolia (trumpet tree), Melochia umbellata (melochia), and Schefflera actinophylla (octopus tree), may take advantage of these opportunities as they do in canopy gaps elsewhere on the island (Zimmerman et al. 2008). Although it is present at low abundance in the planted forest, the native dominant $M$. polymorpha is unlikely to take advantage of these regeneration opportunities due to particularly low abundance of low-statured stems and seedlings that would be likely to benefit from gaps. Furthermore, $M$. polymorpha has failed to succeed in a myriad of light and nutrient conditions in both lowland native and exoticdominated forests across the island (Hughes and Denslow 2005, Mascaro et al. 2008, Zimmerman et al. 2008). As suggested by Mueller-Dombois (2008), monodominance in many ecosystems by $M$. polymorpha is in decline, and a new natural dynamic has taken course, driven primarily by introduced species with a few natives remaining.

Left unaltered, the planted area will gradually transition from an identifiable plantation to something more resembling a novel ecosystem (sensu Hobbs et al. 2006), one in which introduced species dominate but where human intervention is absent. In this context, the Muliwai region may have considerable value as a predictor of future forests; it is much older than other novel ecosystems that are rapidly increasing on Hawai' $i$ Island (Mascaro et al. 2008). On the other hand, if enhanced abundance of native species is desirable, the future for natives could also be altered deliberately by land management. A traditional effort to remove all introduced species would be enormously expensive and likely counterproductive. Removing nearly the entire plantation would create a very high light environment that, on other parts of Hawai'i Island, has resulted in complete dominance by introduced pioneer species (Mascaro et al. 2008). An alternative that has proved to be cost-effective elsewhere may be to target control efforts in the understory of the plantation while keeping the canopy trees intact (see Kueffer et al. 2007). In this way, forest succession could be steered gently toward higher native abundance, without causing the type of interruption that would surely benefit opportunistic introduced species.

A limitation of this study is that the relict native forest is far from pristine, and thus although it serves as a baseline for the abundance of native tree species that might be found in a typical lowland native forest today, all of which contain introduced species (Zimmerman et al. 2008), it cannot act as a baseline for the richness and abundance of native species in the Muliwai area before human contact. However, because this precontact baseline is fundamentally unknowable, the relict forest provides the best available reference community for the purpose of understanding contemporary community shifts.

Although native species (notably $M$. polymorpha) are unlikely to attain dominance in the planted forest studied here, the shadetolerant species $P$. odorata and $P$. hawaiiensis are currently found at comparable or (in the case of $P$. odorata) higher abundance in the planted forest compared with an adjacent relict native forest. The continued presence and strong recruitment of these species after $80 \mathrm{yr}$ of succession with a wide diversity of 
introduced species, both planted and nonplanted, suggest that they are likely to persist in this region of Hawai'i Island for some time.

\section{ACKNOWLEDGMENTS}

I thank S. Bergfeld and the Hawai'i Division of Forestry and Wildlife for granting site access, J. Brown and R. McDowell for field assistance, and two anonymous reviewers for comments on an early draft of the manuscript.

\section{Literature Cited}

Asner, G. P., R. F. Hughes, P. M. Vitousek, D. E. Knapp, T. Kennedy-Bowdoin, J. Boardman, R. E. Martin, M. Eastwood, and R. O. Green. 2008. Invasive plants transform the three-dimensional structure of rain forests. Proc. Natl. Acad. Sci. U.S.A. 105:4519-4523.

Cabin, R. J., S. G. Weller, D. H. Lorence, T. W. Flynn, A. K. Sakai, D. Sandquist, and L. J. Hadway. 2000. Effects of longterm ungulate exclusion and recent alien species control on the preservation and restoration of a Hawaiian tropical dry forest. Conserv. Biol. 14:439-453.

Constantinides, M., and R. J. Cannarella. 1999. A timber inventory of the Waiakea Timber Management Area. The State of Hawai' $i$, Division of Forestry and Wildlife, Honolulu.

Denslow, J. S. 1980. Gap partitioning among tropical rainforest trees. Biotropica 12:4755.

Egler, F. E. 1942. Indigene versus alien in the development of arid Hawaiian vegetation. Ecology 23:14-23.

Ewel, J. J., and F. E. Putz. 2004. A place for alien species in ecosystem restoration. Front. Ecol. Environ. 2:354-360.

Foster, J. T., and S. K. Robinson. 2007. Introduced birds and the fate of Hawaiian rainforests. Conserv. Biol. 21:1248-1257.

Funk, J. L., and P. M. Vitousek. 2007. Resource-use efficiency and plant invasion in low-resource systems. Nature (Lond.) 446:1079-1081.
Giambelluca, T. W., M. A. Nullet, and T. A. Schroeder. 1986. Rainfall atlas of Hawai'i. State of Hawai'i, Department of Land and Natural Resources, Division of Water and Land Development. Honolulu.

Harrington, R. A., and J. J. Ewel. 1997. Invasibility of tree plantations by native and non-indigenous plant species in Hawaii. For. Ecol. Manage. 99:153-162.

Hobbs, R. J., S. Arico, J. Aronson, J. S. Brown, P. Bridgewater, V. A. Cramer, P. R. Epstein, J. J. Ewel, C. A. Klink, A. E. Lugo, D. Norton, D. Ojima, D. M. Richardson, E. W. Sanderson, F. Valladares, M. Vilà, R. Zamora, and M. Zobel. 2006. Novel ecosystems: Theoretical and management aspects of the new ecological world order. Glob. Ecol. Biogeogr. 15:17.

Hughes, R. F., and J. S. Denslow. 2005. Invasion by a $\mathrm{N}_{2}$-fixing tree, Falcataria moluccana, alters function, composition, and structure in wet lowland forests of $\mathrm{Ha}$ wai'i. Ecol. Appl. 15:1615-1628.

Joe, S. M., and C. C. Daehler. 2008. Invasive slugs as under-appreciated obstacles to rare plant restoration: Evidence from the $\mathrm{Ha}-$ waiian Islands. Biol. Invasions 10:245-255.

Kueffer, C., E. Schumacher, K. Fleischmann, P. J. Edwards, and H. Dietz. 2007. Strong belowground competition shapes tree regeneration in invasive Cinnamomum verum forests. J. Ecol. 95:273-282.

Lugo, A. E. 2004. The outcome of alien tree invasions in Puerto Rico. Front. Ecol. Environ. 2:265-273.

Mascaro, J., K. K. Becklund, R. F. Hughes, and S. A. Schnitzer. 2008. Limited native plant regeneration in novel, exoticdominated forests on Hawai'i. For. Ecol. Manage. 256:593-606.

Mueller-Dombois, D. 2008. Pacific island forests: Successionally impoverished and now threatened to be overgrown by aliens? Pac. Sci. 62:303-308.

Ostertag, R., S. Cordell, J. Michaud, T. C. Cole, J. R. Schulten, K. M. Publico, and J. H. Enoka. 2009. Ecosystem and restoration consequences of invasive woody species removal in Hawaiian lowland wet forest. Ecosystems 12:503-515. 
Ostertag, R., C. P. Giardina, and S. Cordell. 2008. Understory colonization of Eucalyptus plantations in Hawaii in relation to light and nutrient levels. Restor. Ecol. 16:475-485.

Sweetapple, P. J., and G. Nugent. 2004. A simple method for assessing ungulate impacts on forest understories. Wildl. Soc. Bull. 32:137-147.

U.S. Department of Agriculture. 2009. Web soil survey. http://websoilsurvey.nrcs.usda .gov/, accessed 5 May 2009.

Wagner, W. L., D. R. Herbst, and S. H. Sohmer. 1999. Manual of the flowering plants of Hawai'i. University of Hawai'i Press/Bishop Museum Press, Honolulu.

Wolfe, E. W., and J. Morris. 1996. Geologic map of the island of Hawai'i. Map I-2524A. U.S. Geological Survey, Denver.

Woodcock, D. 2003. To restore the watersheds: Early twentieth-century tree planting in Hawai'i. Ann. Assoc. Am. Geogr. 93:624-635.

Woodcock, D. W., J. L. Perry, and T. W. Giambelluca. 1999. Occurrence of indigenous plant species in a middle-elevation Melaleuca plantation on O'ahu (Hawaiian Islands). Pac. Sci. 53:159-167.

Zimmerman, N., R. F. Hughes, S. Cordell, P. Hart, H. K. Chang, D. Perez, R. K. Like, and R. Ostertag. 2008. Patterns of primary succession of native and introduced plants in lowland wet forests in eastern Hawai' $i$. Biotropica 40:277-284. 
Appendix

Abundance, Basal Area, and Stem Density of All Species Encountered in 26 Planted and 20 Relict Forest Plots $\left(500 \mathrm{~m}^{2}\right)$ in the Muliwai Region of the Kohala Forest Reserve on Hawai'i Island

\begin{tabular}{|c|c|c|c|c|c|c|c|c|c|c|c|}
\hline \multirow[b]{2}{*}{ Species } & \multirow[b]{2}{*}{ Origin } & \multicolumn{5}{|c|}{ Planted } & \multicolumn{5}{|c|}{ Relict } \\
\hline & & $\begin{array}{l}\text { No. of } \\
\text { Plots }\end{array}$ & $\begin{array}{c}\text { Mean } \\
\text { Basal Area } \\
\left(\mathrm{m}^{2} / \mathrm{ha}\right)\end{array}$ & $\mathrm{SE}$ & $\begin{array}{c}\text { Mean } \\
\text { Density } \\
\text { (stems/ha) }\end{array}$ & SE & $\begin{array}{l}\text { No. of } \\
\text { Plots }\end{array}$ & $\begin{array}{c}\text { Mean } \\
\text { Basal Area } \\
\left(\mathrm{m}^{2} / \mathrm{ha}\right)\end{array}$ & SE & $\begin{array}{c}\text { Mean } \\
\text { Density } \\
\text { (stems/ha) }\end{array}$ & SE \\
\hline Acacia confusa & Nonnative & 2 & 0.12 & $(0.11)$ & 7 & (6) & & & & & \\
\hline $\begin{array}{l}\text { Aleurites moluccana } \\
\text { (standing dead) }\end{array}$ & Nonnative & 1 & 0.01 & & 1 & & $\begin{array}{l}3 \\
1\end{array}$ & $\begin{array}{r}0.73 \\
<0.01\end{array}$ & $(0.41)$ & $\begin{array}{r}26 \\
1\end{array}$ & (16) \\
\hline $\begin{array}{l}\text { Alnus nepalensis } \\
\quad \text { (standing dead) }\end{array}$ & Nonnative & & & & & & $\begin{array}{l}2 \\
1\end{array}$ & $\begin{array}{r}0.14 \\
<0.01\end{array}$ & $(0.12)$ & $\begin{array}{r}31 \\
2\end{array}$ & $(22)$ \\
\hline $\begin{array}{l}\text { Antidesma platyphyllum } \\
\text { (standing dead) }\end{array}$ & Native & & & & & & $\begin{array}{l}11 \\
10\end{array}$ & $\begin{array}{l}0.55 \\
0.17\end{array}$ & $\begin{array}{l}(0.19) \\
(0.08)\end{array}$ & $\begin{array}{l}158 \\
174\end{array}$ & $\begin{array}{l}(52) \\
(62)\end{array}$ \\
\hline $\begin{array}{l}\text { Araucaria columnaris } \\
\text { (standing dead) }\end{array}$ & Nonnative & $\begin{array}{r}15 \\
8\end{array}$ & $\begin{array}{l}3.30 \\
0.03\end{array}$ & $\begin{array}{l}(1.33) \\
(0.01)\end{array}$ & $\begin{array}{r}1,172 \\
87\end{array}$ & $\begin{array}{r}(395) \\
(33)\end{array}$ & $\begin{array}{l}2 \\
2\end{array}$ & $\begin{array}{l}0.40 \\
0.03\end{array}$ & $\begin{array}{l}(0.38) \\
(0.03)\end{array}$ & $\begin{array}{r}80 \\
7\end{array}$ & $\begin{array}{r}(77) \\
(5)\end{array}$ \\
\hline $\begin{array}{l}\text { Casuarina glauca } \\
\text { (standing dead) }\end{array}$ & Nonnative & $\begin{array}{l}7 \\
6\end{array}$ & $\begin{array}{l}7.43 \\
0.44\end{array}$ & $\begin{array}{l}(3.46) \\
(0.37)\end{array}$ & $\begin{array}{l}865 \\
204\end{array}$ & $\begin{array}{l}(436) \\
(103)\end{array}$ & $\begin{array}{l}3 \\
2\end{array}$ & $\begin{array}{l}0.07 \\
0.05\end{array}$ & $\begin{array}{l}(0.04) \\
(0.05)\end{array}$ & $\begin{array}{r}31 \\
9\end{array}$ & $\begin{array}{r}(19) \\
(7)\end{array}$ \\
\hline Cecropia obtusifolia & Nonnative & & & & & & 1 & 0.07 & & 1 & \\
\hline Cibotium glaucum & Native & 1 & $<0.01$ & & 1 & & 7 & 0.20 & $(0.10)$ & 55 & (21) \\
\hline Cibotium menziesii & Native & & & & & & 6 & 0.43 & $(0.20)$ & 22 & (10) \\
\hline $\begin{array}{l}\text { Citrus limon } \\
\quad \text { (standing dead) }\end{array}$ & Nonnative & 2 & $<0.01$ & $(<0.01)$ & 8 & $(7)$ & $\begin{array}{l}1 \\
1\end{array}$ & $\begin{array}{r}0.08 \\
<0.01\end{array}$ & & $\begin{array}{r}29 \\
1\end{array}$ & \\
\hline $\begin{array}{l}\text { Clidemia birta } \\
\text { Coffea arabica }\end{array}$ & $\begin{array}{l}\text { Nonnative } \\
\text { Nonnative }\end{array}$ & $\begin{array}{r}13 \\
3\end{array}$ & 0.02 & $(0.02)$ & $\begin{array}{l}363 \\
102\end{array}$ & $\begin{array}{r}(159) \\
(72)\end{array}$ & 19 & & & 5,093 & (948) \\
\hline $\begin{array}{l}\text { Cordyline fruticosa } \\
\text { (standing dead) }\end{array}$ & Nonnative & $\begin{array}{r}21 \\
7\end{array}$ & $\begin{array}{l}1.37 \\
0.02\end{array}$ & $\begin{array}{l}(0.47) \\
(0.01)\end{array}$ & $\begin{array}{r}1,760 \\
29\end{array}$ & $\begin{array}{r}(632) \\
(13)\end{array}$ & $\begin{array}{l}19 \\
11\end{array}$ & $\begin{array}{l}4.55 \\
0.03\end{array}$ & $\begin{array}{l}(1.17) \\
(0.02)\end{array}$ & $\begin{array}{r}3,121 \\
29\end{array}$ & $\begin{array}{r}(820) \\
(12)\end{array}$ \\
\hline $\begin{array}{l}\text { Diospyros sandwicensis } \\
\text { (standing dead) }\end{array}$ & Native & 1 & $<0.01$ & & 2 & & $\begin{array}{l}1 \\
1\end{array}$ & $\begin{array}{l}<0.01 \\
<0.01\end{array}$ & & $\begin{array}{l}2 \\
1\end{array}$ & \\
\hline $\begin{array}{l}\text { Eucalyptus robusta } \\
\text { (standing dead) }\end{array}$ & Nonnative & $\begin{array}{l}2 \\
1\end{array}$ & $\begin{array}{l}8.77 \\
0.23\end{array}$ & $(6.08)$ & $\begin{array}{r}17 \\
2\end{array}$ & $(12)$ & & & & & \\
\hline Eugenia sp. & Nonnative & & & & & & 1 & 0.04 & & 8 & \\
\hline $\begin{array}{l}\text { Falcataria moluccana } \\
\text { (standing dead) }\end{array}$ & Nonnative & $\begin{array}{r}14 \\
7\end{array}$ & $\begin{array}{r}13.75 \\
0.17\end{array}$ & $\begin{array}{l}(5.49) \\
(0.10)\end{array}$ & $\begin{array}{l}68 \\
10\end{array}$ & $\begin{array}{r}(32) \\
(5)\end{array}$ & $\begin{array}{l}3 \\
2\end{array}$ & $\begin{array}{l}0.67 \\
0.01\end{array}$ & $\begin{array}{l}(0.61) \\
(0.01)\end{array}$ & $\begin{array}{l}90 \\
37\end{array}$ & $\begin{array}{l}(84) \\
(36)\end{array}$ \\
\hline Ficus elastica & Nonnative & 1 & 0.05 & & 12 & & & & & & \\
\hline $\begin{array}{l}\text { Ficus nota } \\
\quad \text { (standing dead) }\end{array}$ & Nonnative & $\begin{array}{l}6 \\
1\end{array}$ & $\begin{array}{r}0.50 \\
<0.01\end{array}$ & $(0.24)$ & $\begin{array}{r}40 \\
5\end{array}$ & $(18)$ & 1 & 0.12 & & 8 & \\
\hline $\begin{array}{l}\text { Fraxinus ubdei } \\
\quad \text { (standing dead) }\end{array}$ & Nonnative & $\begin{array}{r}17 \\
7\end{array}$ & $\begin{array}{l}2.87 \\
0.15\end{array}$ & $\begin{array}{l}(0.92) \\
(0.14)\end{array}$ & $\begin{array}{r}138 \\
13\end{array}$ & $\begin{array}{r}(62) \\
(5)\end{array}$ & $\begin{array}{l}1 \\
1\end{array}$ & $\begin{array}{r}0.44 \\
<0.01\end{array}$ & & $\begin{array}{r}21 \\
3\end{array}$ & \\
\hline
\end{tabular}




\begin{tabular}{|c|c|c|c|c|c|c|c|c|c|c|c|}
\hline Grevillea robusta & Nonnative & 14 & 4.09 & $(1.24)$ & 23 & (6) & 4 & 0.65 & $(0.44)$ & 10 & (5) \\
\hline (standing dead) & & 4 & 0.11 & $(0.06)$ & 3 & (1) & 1 & $<0.01$ & & 1 & \\
\hline Lantana camara & Nonnative & 1 & $<0.01$ & & 2 & & 3 & 0.02 & $(0.01)$ & 13 & (8) \\
\hline Macadamia integrifolia & Nonnative & 10 & 0.12 & $(0.08)$ & 87 & $(58)$ & 1 & $<0.01$ & & 7 & \\
\hline Mangifera indica & Nonnative & 4 & 2.10 & (1.11) & 6 & (3) & & & & & \\
\hline Melaleuca quinquenervia & Nonnative & 13 & 15.36 & $(5.48)$ & 31 & (9) & 1 & 4.02 & & 5 & \\
\hline (standing dead) & & & & & & & 1 & 0.07 & & 2 & \\
\hline Melochia umbellata & Nonnative & 5 & 0.27 & $(0.18)$ & 63 & (43) & & & & & \\
\hline (standing dead) & & 4 & 0.01 & $(<0.01)$ & 9 & (5) & & & & & \\
\hline Metrosideros polymorpha & Native & 6 & 0.83 & $(0.35)$ & 22 & (11) & 20 & 18.54 & (1.98) & 346 & (64) \\
\hline (standing dead) & & 9 & 1.23 & $(0.59)$ & 65 & (30) & 16 & 1.84 & $(0.55)$ & 151 & (61) \\
\hline Myrsine lessertiana & Native & 3 & $<0.01$ & $(<0.01)$ & 2 & (1) & 8 & 0.05 & $(0.02)$ & 25 & (8) \\
\hline (standing dead) & & & & & & & 4 & $<0.01$ & $(<0.01)$ & 4 & (2) \\
\hline Pachira aquatica & Nonnative & 1 & 0.28 & & 99 & & & & & & \\
\hline Persea americana & Nonnative & 3 & 0.01 & $(0.01)$ & 5 & (4) & & & & & \\
\hline (standing dead) & & 1 & $<0.01$ & & 1 & & & & & & \\
\hline Psidium cattleianum & Nonnative & 6 & 0.21 & $(0.11)$ & 142 & $(82)$ & 5 & 0.51 & $(0.45)$ & 284 & $(258)$ \\
\hline (standing dead) & & 2 & $<0.01$ & $(<0.01)$ & 3 & (2) & 1 & $<0.01$ & & 1 & \\
\hline Psidium guajava & Nonnative & 20 & 1.06 & $(0.26)$ & 271 & (74) & 19 & 5.84 & $(0.99)$ & 1,295 & (289) \\
\hline (standing dead) & & 15 & 0.17 & $(0.07)$ & 62 & (17) & 15 & 0.09 & $(0.04)$ & 92 & $(19)$ \\
\hline Psychotria hawaiiensis & Native & 20 & 0.94 & $(0.26)$ & 467 & (89) & 18 & 0.52 & $(0.16)$ & 380 & (86) \\
\hline (standing dead) & & 16 & 0.17 & $(0.06)$ & 128 & (30) & 18 & 0.19 & (0.06) & 232 & (54) \\
\hline Psydrax odorata & Native & 18 & 0.46 & (0.16) & 179 & (59) & 5 & 0.19 & (0.12) & 73 & (46) \\
\hline (standing dead) & & 8 & 0.02 & $(<0.01)$ & 18 & (8) & 2 & 0.07 & $(0.07)$ & 17 & (14) \\
\hline Schefflera actinophylla & Nonnative & 1 & $<0.01$ & & 1 & & 3 & 0.02 & $(0.02)$ & 3 & (2) \\
\hline Schinus terebintbifolius & Nonnative & 1 & 0.10 & & 35 & & 1 & $<0.01$ & & 5 & \\
\hline (standing dead) & & 1 & 0.01 & & 18 & & 1 & $<0.01$ & & 3 & \\
\hline Syzygium jambos & Nonnative & 11 & 2.43 & $(1.04)$ & 1,106 & $(457)$ & 4 & 0.04 & $(0.04)$ & 32 & (27) \\
\hline (standing dead) & & 4 & $<0.01$ & $(<0.01)$ & 30 & $(22)$ & 1 & $<0.01$ & & 3 & \\
\hline Taxodium distichum & Nonnative & 1 & 0.23 & & 1 & & & & & & \\
\hline Terminalia myriocarpa & Nonnative & 2 & 0.63 & $(0.48)$ & 4 & (3) & 1 & $<0.01$ & & 1 & \\
\hline Toona ciliata & Nonnative & 12 & 0.59 & $(0.23)$ & 46 & (23) & 7 & 1.27 & $(0.66)$ & 105 & (61) \\
\hline (standing dead) & & 4 & 0.01 & $(<0.01)$ & 8 & (5) & 3 & 0.02 & $(0.01)$ & 13 & (10) \\
\hline Wikstroemia sp. & Native & & & & & & 1 & $<0.01$ & & 4 & \\
\hline Standing dead unknown & Unknown & 15 & 0.11 & $(0.05)$ & 40 & (14) & 13 & 0.14 & $(0.05)$ & 60 & $(15)$ \\
\hline Totals & & 26 & 70.81 & $(8.42)$ & 7,883 & $(1,021)$ & 20 & 42.93 & $(4.00)$ & 12,207 & $(1,158)$ \\
\hline
\end{tabular}

Note: Boldface indicates native species.

a Clidemia hirta stems were counted at the base and not included in basal area measurements (see Materials and Methods). 
